\title{
nKAJIAN PERBANDINGAN TEPUNG SORGUM (Sorghum bicolor) DENGAN TEPUNG GANYONG (Canna edulis) DAN KONSENTRASI IKAN KEMBUNG (Rastrelliger kanagurta L) TERHADAP KARAKTERISTIK NUGGET
}

\author{
Wisnu Cahyadi \\ Thomas Gozali \\ Dea Ayu Ramdiani
} Program Studi Teknologi Pangan, Fakultas Teknik, Universitas Pasundan, Jl. Dr.Setiabudi No 93, Bandung, 40153,
Indonesia

E-mail : wisnucahyadi@unpas.ac.id

\begin{abstract}
Abstrak
Tujuan penelitian ini adalah menentukan perbandingan tepung sorgum dengan tepung ganyong dan konsentrasi ikan kembung pada karakteristik nugget. Manfaat dari penelitian ini adalah untuk memanfaatkan dan meningkatkan produktivitas pangan lokal sebagai diversifikasi makanan yang dapat diterima oleh masyarakat, memberikan informasi tentang bahan-bahan alternatif yang terbuat dari tepung sorgum, tepung ganyong dan ikan kembung sebagai komoditas lokal, serta meningkatkan penggunaan nilai dan nilai ekonomi dari tepung sorgum, tepung ganyong dan ikan kembung. Metode penelitian ini dilakukan penelitian pendahuluan dan penelitian utama. Penelitian pendahuluan yang dilakukan adalah menganalisis kadar air bahan baku untuk tepung sorgum dan tepung ganyong. Rancangan yang digunakan dalam penelitian ini adalah rancangan acak kelompok (RAK) faktorial 3X3 dengan tiga ulangan. Faktor pertama adalah perbandingan tepung sorgum dengan tepung ganyong $(1: 2,2: 2$, dan 2: 1) dan faktor kedua adalah konsentrasi ikan kembung $(50 \%, 55 \%$, dan 60\%). Respon variabel dalam penelitian ini adalah uji organoleptik termasuk warna, rasa, tekstur dan rasa. Respon kimia meliputi penentuan kadar air, kandungan karbohidrat, kandungan protein, kandungan lemak, dan kandungan serat. Hasil penelitian menunjukkan bahwa pada tepung sorgum 10,78\% kadar air dan pada tepung ganyong adalah 10,29\%. Berdasarkan hasil pemilihan sampel terbaik, produk yang dipilih diperoleh dalam perlakuan a2b3 dari perbandingan tepung sorgum dengan tepung ganyong (1: 1) dan konsentrasi ikan kembung (60\%) dengan kadar air 51,63\%, protein 14,73\%, lemak 5,47\%, karbohidrat 6,35\%, dan serat kasar 3,90\%.
\end{abstract}

\begin{abstract}
Nugget is a processed meat product that has a delicious and distinctive taste. This study utilizes puffed fish (mackerel), sorghum flour and canna (ganyong) flour as raw material. The purpose of this study was determined the ratio of sorghum flour to canna flour and the concentration of mackerel on the characteristics of nuggets. The benefits of this study are to utilize and improve local food productivity as a diversification of food that can be accepted by the community, provided information about alternative ingredients made from sorghum flour, canna flour and mackerel as local commodities, as well as increase the use value and economic value of sorghum flour, Canna flour and mackerel.

The research method were carried out preliminary research and primary research. Preliminary research conducted was analyzed the water content of raw material for sorghum flour and canna flour. The design used in this study was a randomized block design (RBD) 3X3 factorial pattern with three replications. The first factor was the ratio of sorghum flour to canna flour (1:2, 2: 2, and 2: 1) and the second factor was the concentration of mackerel $(50 \%, 55 \%$, and $60 \%)$. The response variables in this study was organoleptic tests including color, flavour, texture and taste. Chemical response includes determination of water content, carbohydrate content, protein content, fat content, and fiber content. The result showed that on sorghum flour were $10.78 \%$ moisture content and on canna flour were $10,29 \%$ moisture content. Based on the results selection of the best sample, the selected product was obtained in the a2b3 treatment of the ratio of sorgun flour to canna flour (1: 1) and the concentration of mackerel (60\%) with a moisture content of 51.63\%, protein $14.73 \%$, fat $5,47 \%$, carbohydrates $6.35 \%$, and crude fiber $3.90 \%$.
\end{abstract}

Keywords: sorghum flour, canna flour, mackerel, nuggets. 


\section{Pendahuluan}

Indonesia memiliki sumber pangan lokal yang melimpah dan beranekaragam jenis yang sangat berpotensi untuk dikembangkan. Berbagai upaya menunjang program ketahanan pangan nasional dilakukan untuk memaksimalkan produksi dan konsumsi bahan pangan lokal sumber karbohidrat non beras dan non terigu yang menjadi prioritas pemerintah terutama dalam bidang diversifikasi. Diversifikasi pangan dilakukan dengan memperhatikan sumber daya lokal melalui peningkatan teknologi pengolahan dan produk pangan serta peningkatan kesadaran masyarakat untuk mengkonsumsi anekaragam pangan dengan gizi seimbang (Papunas,2013).

Ketergantungan masyarakat Indonesia pada bahan pangan tertentu dapat melemahkan ketahanan pangan nasional dilihat dari tingkat impor gandum dan tepung terigu yang masih tinggi (Amalia, 2013). Indonesia memiliki beberapa komoditi lokal yang berpotensi sebagai makanan pokok pengganti gandum dan tepung terigu salah satunya adalah sorgum (Sorghum bicolor) dan ganyong (Canna edulis).

Sorgum merupakan bahan pangan yang juga mengandung karbohidrat seperti beras, terigu dan jagung. Sorgum adalah salah satu bahan pangan yang potensial untuk substitusi terigu dan beras karena masih satu famili dengan gandum dan padi, hanya berbeda subfamili, sehingga karakteristik tepungnya relatif lebih baik dibanding tepung umbi-umbian. Oleh karena itu sorgum merupakan pengganti karbohidrat alternatif. Selain sebagai sumber karbohidrat, sorgum memiliki kandungan protein, kalsium dan vitamin B1 yang lebih tinggi dibanding beras dan jagung sehingga tanaman sorgum sangat potensial sebagai bahan pangan utama (Suarni, 2012).

Ganyong (Canna edulis) merupakan tanaman yang efisien dalam penggunaan nitrogen, toleran terhadap kekeringan dan produktivitas yang tinggi. Seperti halnya ubi jalar, ganyong menyimpan cadangan makanannya dalam bentuk pati pada akar yang dapat dikonsumsi namun memiliki kendala karena banyak mengandung serat dan mudah berwarna coklat. Sebelum dikonsumsi, ganyong harus direbus beberapa jam, sehingga jarang dikonsumsi masyarakat (Hidayat dkk,2008).

Ikan merupakan salah satu sumber protein hewani yang banyak dikonsumsi masyarakat, kandungan protein ikan erat sekali kaitannya dengan kandungan lemakdan airnya. Ikan yang mengandung lemak rendah rata-rata memiliki protein dan jumlah besar, sedangkan pada ikan gemuk sebaliknya. Kandungan protein ikan umumnya lebih tinggi jika dibandingkan dengan hewan darat yang akan menghasilkan kalori lebih tinggi dan protein memegang peranan penting dalam pembentukan jaringan. Daging ikan mengandung sedikit sekali tenunan pengikat (tendon), sehingga sangat mudah dicerna oleh enzi autolisis. Hasil pencernaan itu menyebabkan daging lunak sehingga menjadi media yang cocok untuk pertumbuhan mikroorganisme. Kandungan protein pada daging ikan cukup tinggi, mencapai $20 \%$ dan tersusun atas sejumlah asam amino yang berpola mendekati pola kebutuhan asam amino di dalam tubuh manusia (Adawyah, 2007).

Ikan kembung (Rastrelliger sp) merupakan spesies dengan populasi yang terbanyak yang hidup diseluruh wilayah perairan Indonesia. Oleh karenanya ikan kembung sangat mudah didapat dipasaran dengan harga yang relatif terjangkau dan banyak dikonsumsi oleh sebagian masyarakat Indonesia (Direktorat Jendral Perikanan, 1990).

Pemanfaatan ikan kembung jantan banyak digunakan oleh masyarakat luas karena ikan kembung banyak mengandung omega 3 dan omega 6 yang baik bagi pencegahan penyakit dan kecerdasan otak. Omega 3 dan omega 6 termasuk dalam asam lemak tak jenuh jamak esensial yang berguna untuk memperkuat daya tahan otat jantung, meningkatkan kecerdasan otak, menurunkan kadar trigliserida dan mencegah penggumpalan darah (Irmawan, 2009).

Salah satu produk yang dapat dibuat dari bahan baku tepung sorgum, tepung ganyong dan ikan kembung adalah nugget. Nugget merupakan daging yang dicincang, kemudian diberi bumbu-bumbu (bawang putih, garam, bumbu penyedap, dan merica), dicetak dalam suatu wadah dan dikukus. Selanjutnya, adonan didinginkan dan dipotong-potong atau dicetak dalam bentuk yang lebih kecil, kemudian dicelupkan dalam putih telur dan digulingkan kedalam tepung panir sebelum digorang. Nugget memiliki rasa yang lebih gurih daripada daging utuh (Tati, 1998). Pembutan nugget mencakup lima tahap, yaitu penggilingan yang disertai pencampuran bumbu, es, bahan tambahan, pencetakan, pelapisan perekat tepung dan pelumuran tepung roti, penggorengan awal (frefrying) dan pembekuan (Aswar, 1995).

Identifikasi masalah dalam penelitian ini adalah mengetahui bagaimana pengaruh perbandingan tepung sorgum dengan tepung ganyong, pengaruh konsentrasi ikan kembung dan interaksi antara perbandingan tepung sorgum dengan tepung ganyong serta konsentrasi ikan kembung terhadap karakteristik nugget.

Manfaat penelitian ini adalah untuk meningkatkan pangan lokal sebagai diversifikasi pangan yang dapat diterima oleh masyarakat.

\section{Bahan dan Metode Penelitian}

Bahan yang digunakan dalam penelitian adalah tepung sorgum, tepung ganyong, ikan kembung, es batu, bawang putih, bawang bombay, gula, garam, merica, telur, susu skim,tepung maizena, tepung panir.

Bahan yang digunakan untuk analisis adalah aquadest, $\mathrm{NaoH}, \mathrm{H}_{2} \mathrm{SO}_{4}$, larutan luffschoorl, Larutan $\mathrm{KI}, \mathrm{Na}_{2} \mathrm{~S}_{2} \mathrm{O}_{3}, \mathrm{HCl}$, dan indikator phenoftalin.

Tahap I. Analisis Kadar Air Bahan Baku 
Analisis ini dilakukan untuk mengetahui kadar air yang terdapat pada bahan baku yaitu tepung sorgum dan tepung ganyong yang akan digunakan pada penelitian utama.

\section{Tahap II. Penentuan Respon}

Penelitian utama dilakukan untuk menentukan perbandingan tepung sorgum dan tepung ganyong serta konsentrasi ikan kembung pada pembuatan nugget. Penelitian utama ini terdiri dari rancangan perlakuan, rancangan percobaan, rancangan analisis, dan rancangan respon.

\section{Rancangan Respon}

Rancangan respon yang akan dilakukan pada penelitian ini meliputi respon kimia dan organoleptik.

\section{Respon Kimia}

Respon kimia yang dilakukan terhadap produk akhir flakes meliputi :

- Analisis kadar air dengan metode Gravimetri (AOAC, 1995).

- Analisis kadar karbohidrat dengan motode Luff's Schoorl (Sudarmadji dkk, 2010).

- Analisis kadar protein metode Kjedahl (AOAC, 1995)

- Analisis kadar serat metode Gravimetri (Sudarmadji dkk, 1996)

- Analisis kadar lemak metode Ekstraksi (Sudarmadji dkk, 200)

2. Respon Organoleptik

Respon yang diuji terhadap nugget yang dihasilkan meliputi warna, aroma, tekstur dan rasa.

\section{Hasil dan Pembahasan}

Penelitian pendahuluan yang dilakukan adalah analisis bahan baku nugget. Tujuan dilakukannya analisis bahan baku ini yaitu untuk mengetahui kandungan zat gizi dalam nugget yang akan digunakan untuk pembuatan nugget yaitu tepung sorgum dan tepung ganyong. Analisis kimia yang dilakukan yaitu analisis kadar air dengan menggunakan metode gravimetri.

Tabel 1. Hasil Analisis Kadar Air Tepung sorgum dan Tepung Ganyong

\begin{tabular}{|c|c|}
\hline Kadar Air & Hasil \\
\hline Tepung Sorgum & $10,78 \%$ \\
\hline Tepung Ganyong & $10,29 \%$ \\
\hline
\end{tabular}

Kandungan kadar air yang terkandung pada tepung sorgum adalah sebesar 10,37\% dan untuk kadar air tepung sorgum sebesar 10,29\%. Nilai kadar air pada tepung sorgum lebih rendah daripada kadar air pada penelitian Suarni dan Firmansyah (2005) yaitu 11,02\%. Sedangkan nilai kadar air pada tepung ganyong lebih rendah daripada kadar air pada penelitian Ratnaningsih dkk (2010) yaitu 14\%. Perbedaan kadar air tersebut dipengaruhi oleh lama pengeringan dan suhu yang digunakan sehingga pengeringan lebih optimal.
Penelitian utama merupakan penelitian untuk menentukan perbandingan tepung sorgum dan tepung ganyong dan konsentrasi ikan kembung pada pembuatan nugget. Pada penelitian utama ini dilakukan pembuatan produk nugget dengan perbandingan tepung sorgum dan tepung ganyong serta konsentrasi ikan kembung yang berbeda.

Penelitian utama terdiri dari respon organoletik dengan uji hedonik meliputi atribut warna, aroma, tekstur, dan rasa dan respon kimia yaitu analisis kadar air, kadar protein dan kadar lemak serta sampel terpilih akan dilakukan analisis kadar serat dan kadar pati.

\section{Respon Kimia \\ Kadar Air}

Berdasarkan hasil perhitungan analisis Variasi (ANAVA) terhadap kadar air produk nugget menunjukkan bahwa perbandingan tepung sorgum dengan tepung ganyong berpengaruh nyata terhadap kadar air. Hasil uji lanjut terhadap kadar air dapat dilihat pada Tabel 2.

Tabel 2. Pengaruh Perbandingan Tepung Sorgum dan Tepung Ganyong Tehadap Kadar Air Produk Nugget

\begin{tabular}{|c|c|}
\hline Perlakuan & Hasil Rata-Rata \\
\hline $\mathrm{a} 1(1: 2)$ & $49.64 \mathrm{a}$ \\
\hline $\mathrm{a} 2(1: 1)$ & $52.52 \mathrm{~b}$ \\
\hline $\mathrm{a} 3(2: 1)$ & $56.61 \mathrm{c}$ \\
\hline
\end{tabular}

Keterangan : Nilai rata-rata yang ditandai dengan huruf berbeda menunjukkan perbedaan nyata pada Uji Lanjut Duncan 5\%.

Berdasarkan tabel 2 menunjukkan bahwa semakin banyak tepung sorgum yang ditambahkan maka kadar air pada nugget akan semakin tinggi. Hal ini disebabkan karena daya serap air tepung sorgum rendah yaitu sebesar $1,51 \%$. Daya serap ini berkaitan dengan komposisi amilosa dan amilopektin pati dari tepung sorgum. Kadar amilosa sorgum sekitar 23-28\%, sisanya adalah amilopektin. Rendahnya kadar amilosa tepung sorgum menyebabkan nilai pengembangan volume akan semakin rendah. Hal itu karena dengan kadar amilosa yang tinggi maka menyerap air lebih banyak sehingga volume juga semakin besar, begitu pula sebaliknya (Yuli, 2009).

Faktor yang dapat mempengaruhi daya serap air adalah serat, semakin tinggi kandungan serat suatu bahan maka kemampuan mengikat airnya semakin tinggi. Menurut Gordon (1989), serat mempunyai pengaruh pada daya serap air suatu bahan karena mempunyai kemampuan mengikat air.

\section{Kadar Protein}

Berdasarkan hasil perhitungan analisis variasi (ANAVA) terhadap kadar protein produk nugget menunjukkan bahwa perbandingan tepung sorgum dengan tepung ganyong dan konsentrasi ikan kembung berpengaruh nyata terhadap kadar protein. Hasil uji lanjut dapat dilihat pada Tabel 3 dan Tabel 4. 
Tabel 3. Pengaruh Perbandingan Tepung Sorgum dan Tepung Ganyong Terhadap kadar Protein Produk Nugget

\begin{tabular}{|c|c|}
\hline Perlakuan & Hasil Rata-Rata \\
\hline a1 $(1: 2)$ & $14.13 \mathrm{a}$ \\
\hline $\mathrm{a} 2(1: 1)$ & $14.25 \mathrm{~b}$ \\
\hline $\mathrm{a} 3(2: 1)$ & $14.60 \mathrm{c}$ \\
\hline
\end{tabular}

Keterangan : Nilai rata-rata yang ditandai dengan huruf berbeda menunjukkan perbedaan nyata pada Uji Lanjut Duncan 5\%.

Berdasarkan tabel 3 dapat diketahui bahwa semakin tinggi konsentrasi tepung sorgum yang ditambahkan maka kadar protein pada nugget semakin tinggi. Hal ini disebabkan karena tepung sorgum mengandunng protein tinggi sebesar sebesar 10,11\% sehingga semakin banyak konsentrasi tepung sorgum yang ditambahkan akan meningkatkan kadar protein pada nugget ikan yang dihasilkan (Suyatno, 2010).

Menurut Lasztity (2000), jenis protein yang dominan pada sorgum, yaitu karifin (sekitar 32,6$58,8 \%$ dari total protein). Karifin ini termasuk kedalam jenis protein proalamin. Selain itu, pada sorgum juga terdapat juga terdapat protein glutenin $(19,0-37,4 \%)$, albumin $(1,3-7,7 \%)$ dan globulin $(2,0-9,3 \%)$.

Tabel 4. Pengaruh Konsentrasi Ikan Kembung Terhadap Kadar Protein Produk Nugget

\begin{tabular}{|c|c|}
\hline Perlakuan & Hasil Rata-Rata \\
\hline b1 50\% & $13.85 \mathrm{a}$ \\
\hline b2 55\% & $14.30 \mathrm{~b}$ \\
\hline b3 60\% & $14.83 \mathrm{c}$ \\
\hline
\end{tabular}

Keterangan : Nilai rata-rata yang ditandai dengan huruf berbeda menunjukkan perbedaan nyata pada Uji Lanjut Duncan 5\%.

Berdasarkan tabel 4 menunjukkan bahwa semakin tinggi penambahan konsentrasi ikan kembung, maka kadar protein nugget yang dihasilkan akan semakin tinggi. Hal ini disebabkan karena ikan kembung memiliki kadar protein yang tinggi yaitu sebesar $22 \%$. Menurut Ramdani (2016), perlakuan penambahan ikan kembung 50\% menghasilkan nugget ikan dengan kadar protein paling rendah yaitu 11,647, kadar protein meningkat pada perlakuan penambahan ikan kembung $70 \%$ menghasilkan nugget ikan dengan kadar protein sbesar 16,107\%. Dengan semakin meningkatnya penambahan konsentrasi ikan kembung maka kadar protein nugget ikan akan semakin naik.

Pada ikan yang kandungan proteinnya tinggi maka akan diperoleh kadar protein yang tinggi pula pada produk, semakin lama pengukusan, menyebabkan kadar protein pada nugget ikan kembung akan meningkat. Proses pemanasan dengan suhu yang tinggi mengakibatkan kadar air menyusut, sehingga kadar protein dari suatu bahan akan lebih tinggi.

Berdasarkan hasil perhitungan analisis variasi (ANAVA) terhadap kadar lemak produk nugget menunjukkan bahwa perbandingan tepung sorgum dengan tepung ganyong dan konsentrasi ikan kembung serta interaksi keduanya tidak berpengaruh terhadap kadar lemak.

Setiap perlakuan memiliki kadar lemak yang rendah. Kandungan lemak yang rendah dipengaruhi dari bahan dasar yang dicampurkan pada produk nugget ikan kembung. Bahan dasar yang digunakan yaitu tepung sorgum, tepung ganyong dan ikan kembung. Ketiga bahan dasar tersebut memiliki kadar kadar lemak yang rendah sehingga berdampak pada kandungan lemaknya. Kadar lemak pada tepung sorgum sebesar $3,65 \%$, pada tepung ganyong sebesar $1,22 \%$, dan pada ikan kembung $1 \%$.

Menurut Dhevina Widhia A (2010), kadar lemak nugget yang tidak berbeda nyata dipengaruhi juga oleh kadar air nugget. Kataren (1986) menyatakan penurunan kadar air terjadi karena panas yang disalurkan melalui minyak goreng yang berakibat menguapkan air yang terdapat dalam bahan. Hal ini menunjukan bahwa kadar air berkolerasi negative dengan kadar lemak.

\section{Respon Organoleptik Warna}

Berdasarkan hasil perhitungan analisis variansi (ANAVA) terhadap warna produk nugget menunjukkan bahwa perbandingan tepung sorgum dengan tepung ganyong dan konsentrasi ikan kembung serta interaksi keduanya tidak berpengaruh terhadap warna.

Perbandingan tepung sorgum dengan tepung ganyong dan konsentrasi ikan kembung maupun interaksinya tidak berpungaruh terhadap warna yang ditimbulkan. Nilai rata-rata kesukaan yang diberikan dari 30 panelis untuk atribut warna kisaran tidak suka. Warna nugget cenderung agak keabu-abuan dan agak coklat pada bagian dalamnya.

Kataren (1986), menyatakan bahwa penggorengan dengan minyak menyebabkan perubahan warna bahan menjadi kuning keemasan. Warna ini timbul karena terjadi reaksi pencoklatan (browning) akibat pemanasan komponen pati dan protein yang beasal dari tepung, dan tepung panir.

Winarno (2002), terjadinya reaksi pencoklatan karena adanya reaksi Maillard yang merupakan reaksi antara karbohidrat, khususnya gula pereduksi dengan gugus amina primer. Hasil reaksi tersebut menghasilkan warna coklat yang sangat dikehendaki dalam pengolahan pangan.

\section{Aroma}

Berdasarkan hasil Perhitungan analisis variansi (ANAVA) terhadap aroma produk nugget menunjukkan bahwa konsentrasi ikan kembung berpengaruh nyata terhadap aroma. Hasil uji lanjut dapat dilihat pada tabel 5 . 
Tabel 5. Pengaruh Konsentrasi Ikan Kembung Terhadap Aroma Produk Nugget

\begin{tabular}{|c|c|}
\hline Perlakuan & Hasil Rata-Rata \\
\hline b1 50\% & $3.49 \mathrm{a}$ \\
\hline b2 55\% & $4.02 \mathrm{~b}$ \\
\hline b3 60\% & $4.29 \mathrm{c}$ \\
\hline
\end{tabular}

Keterangan : Nilai rata-rata yang ditandai dengan huruf berbeda menunjukkan perbedaan nyata pada Uji Lanjut Duncan 5\%

Berdasarkan tabel 5 menunjukkan bahwa semakin banyak penambahan konsentrasi ikan kembung maka aroma yang dihasilkan terasa lebih kuat.

Aroma yang paling menonjol dalam pembuatan nugget ikan kembung adalah aroma ikan kembung, karena aroma dari ikan kembung ini berbau amis sehingga dapat menimbulkan aroma yang khas.

Komponen volatil yang terutama berperan dalam pembentukan cita rasa pada daging atau ikan setelah dimasak, hal ini secara mudah dapat dicium oleh hidung. Dimana aroma banyak dipengaruhi oleh prekursor yang larut dalam air dan lemak dari bumbu bumbu yang ditambahka (Devi, 2005).

Trimetilamina adalah senyawa organik dengan rumus $\mathrm{N}(\mathrm{CH} 3) 3$ merupakan senyawa yang tidak berwarna, higroskopik, dan mudah terbakar dimana amina tersier yang memiliki bau kuat amis rendah konsentrasi yang tinggi. Bau amis pada ik an

disebabkan oleh dekomposisi kandungan ammonia (senyawa belerang dan bahan kimia hasil pengurain amino). Otot ikan mengandung zat trimetilamina dan dimetilamina. Kedua campuran senyawa inilah yang menimbulkan bau amis pada ikan. Hidung manusia dirancang peka terhadap bau kimia,dan senyawa tersebut sudah mengurai sejak ikan telah mati masih segar, jadi jika dibiarkan semakin lama akan meningkat.

Menurut Chen dkk (2009), aroma nugget dipengaruhi oleh penambahan bumbu dan penyedap rasa seperti lada dan bawang putih, penggunaaan bahan lain seperti susu bubuk skim, tepung roti dan bumbubumbu yang memiliki aroma khas masing-masing.

\section{Tekstur}

Berdasarkan hasil perhitungan analisis variasi (ANAVA) tekstur produk nugget menunjukkan bahwa konsentrasi ikan kembung berpengaruh nyata terhadap tekstur. Hasil uji lanjut dapat dilihat pada tabel 6 .

Tabel 6. Pengaruh Konsentrasi Ikan Kembung Terhadap Tekstur Produk Nugget

\begin{tabular}{|c|c|}
\hline Perlakuan & Hasil Rata-Rata \\
\hline b1 50\% & $4.07 \mathrm{a}$ \\
\hline b2 55\% & $4.10 \mathrm{~b}$ \\
\hline b3 60\% & $4.23 \mathrm{c}$ \\
\hline
\end{tabular}

Keterangan : Nilai rata-rata yang ditandai dengan huruf berbeda menunjukkan perbedaan nyata pada Uji Lanjut Duncan 5\%.
Berdasarkan tabel 6 menunjukkan bahwa semakin tinggi penambahan konsentrasi ikan kembung, maka akan berdampak pada tekstur nugget yang baik dan kompak dan semakin tinggi pula nilai kesukaan panelis. Jika dilihat dari rata-rata nilai kesukaan, nugget dengan konsentrasi ikan $60 \%$ paling disukai oleh panelis. Ikan kembung mengandung protein yang dapat mengikat air sehingga memperbaiki tekstur pada produk nugget. Menurut Widjaksono (2013), stabilitas emulsi adonan dipengaruhi oleh kapasitas pengikatan air dan lemak oleh protein. Stabilitas tercapai bila globula lemak yang terdispersi didalam emulsi diselubungi oleh emulsifier (protein).

Tekstur merupakan sifat tekanan yang diamati dengan mulut (pada waktu digigit dan dikunyah lalu ditelan) ataupun dapat pula dengan perabaan olah jari. Setiap bentuk makanan mempunyai tekstur tersendiri tergantung pada keadaan fisik, ukuran, dan bentuk sel yang dikandungnya. Penilaian tekstur dapat berupa kekrasan, elastisitas atau kerenyahan (Kartika, 1988).

Tekstur merupakan segi penting dari mutu makanan, kadang-kadang lebih penting daripada aroma, rasa dan warna. Tekstur suatu bahan makanan akan mempengaruhi cita rasa yang ditimbulkan oleh bahan tersebut. Perubahan tekstur suatu bahan dapat mengubah rasa dan bau yang timbul karena dapat mempengaruhi kecepatan timbulnya rangsangan terhadap kelenjar air liur (Winarno, 2002 dalam Anggraini, 2012).

\section{Rasa}

Berdasarkan hasil Perhitungan analisis variansi (ANAVA) terhadap aroma produk nugget menunjukkan bahwa konsentrasi ikan kembung berpengaruh nyata terhadap aroma. Hasil uji lanjut dapat dilihat pada tabel 7 .

Tabel 7. Pengaruh Konsentrasi Ikan Kembung Terhadap Rasa Produk Nugget

\begin{tabular}{|c|c|}
\hline Perlakuan & Hasil Rata-Rata \\
\hline b1 50\% & $3.87 \mathrm{a}$ \\
\hline b2 55\% & $4.08 \mathrm{~b}$ \\
\hline b3 60\% & $4.21 \mathrm{c}$ \\
\hline
\end{tabular}

Keterangan : Nilai rata-rata yang ditandai dengan huruf berbeda menunjukkan perbedaan nyata pada Uji Lanjut Duncan 5\%.

Berdasarkan tabel 7 menunjukan bahwa pada perlakuan konsentrasi penambahan ikan kembung berpengaruh terhadap nilai rata-rata atribut rasa dimana semakin tinggi penambahan konsentrasi ikan kembung yang digunakan maka semakin baik cita rasa yang dihasilkan dan semakin tinggi pula nilai kesukaan panelis terhadap rasa dari produk. Pada produk nugget ini rasa yang dapat dirasakan panelis yaitu rasa gurih, akibat dari penambahan ikan kembung dan bahan penunjang seperti telur, susu, dan garam.

Rasa yang muncul pada produk nugget ikan kembung dipengaruhi oleh bahan yang ada pada 
produk seperti ikan kembung dan garam. Ikan kembung memberikan pengaruh yang paling tinggi terhadap rasa gurih pada nugget ikan kembung dari produk akhir, sedangkan garam memberikan sensasi rasa asin dan mempengaruhi citarasa produk nugget ikan kembung (Winarno, 1992).

Rasa merupakan penggabungan dari berbagai bahan dan bumbu yang telah melalui beberapa proses pengolahan. Ketepatan dalam pemberian bumbu dan pengolahan makanan akan mempengaruhi rasa dari suatu produk makanan yang dihasilkan. Rasa adalah faktor yang cukup penting dalam menentukan tingkat penerimaan konsumen terhadap suatu produk makanan. Rasa optimal dapat menunjang produk sehingga dapat diterima oleh konsumen (Winarno, 2002).

Berdasarkan hasil uji organoleptik meliputi warna, aroma, tekstur dan rasa serta respon kimia yaitu kadar air, kadar protein dan kadar lemak. Perlakuan terbaik yang mengacu pada karakteristik nugget yang diinginkan.

Berdasarkan hasil metode skoring bahwa sampel yang terpilih adalah perlakuan a2b3 dengan perbandingan tepung sorgum dengan tepung ganyong yaitu 1:1 dan konsentrasi ikan kembung 60\%. Hasil kadar air 51,63\%, protein $14,73 \%$, lemak 5,47\%. Setelah didapat produk terpilih maka dilakukan uji kadar karbohidrat dan kadar serat kasar dan didapat hasil karbohidrat 6,35\%, dan serat kasar 3,90\%.

Berdasarkan hasil penelitian perbandingan tepung sorgum dengan tepung ganyong serta konsentrasi ikan kembung terhadap karakteristik nugget diperoleh kesimpulan sebagai berikut :

1. Berdasarkan hasil analisis bahan baku yaitu tepung sorgum dan tepung ganyong pada penelitian pendahuluan, didapatkan hasil pada tepung sorgum yaitu kadar air $10,78 \%$ dan pada tepung ganyong yaitu kadar air $10,29 \%$.

2. Perbandingan tepung sorgum dengan tepung ganyong berpengaruh nyata terhadap respon kimia kadar air dan kadar protein, tetapi tidak berpengaruh nyata terhadap kadar lemak dan atribut warna, aroma, tekstur dan rasa.

3. Konsentrasi ikan kembung berpengaruh nyata terhadap respon kimia kadar air dan kadar protein, respon organoleptik atribut aroma, tekstur, dan rasa, tetapi tidak berpengaruh nyata terhadap kadar lemak dan atribut warna.

4. Berdasarkan hasil penelitian utama produk nugget yang terpilih secara respon kimia dan respon organoleptik adalah perlakuan a2b3 perbandingan tepung sorgum dengan tepung ganyong 1:1 dan konsentrasi ikan kembung 60\%. Didapatkan hasil kadar air 51,63\%, protein $14,73 \%$, lemak 5,47\%, karbohidrat 6,35\%, dan serat kasar 3,90\%.

\section{Daftar Pustaka}

1. Adawyah, R. 2007. Pengolahan dan Pengaweta Ikan. Bumi Aksara. Jakarta.
2. Chen, G., H.song dan Ch. Ma. 2009. Aroma-active compounds of Beijing roast duck. Flavor and Fragrance Journal, Volume 24 (4): 186-191.

3. Direktorat Jendral Perikanan. 1990. Sumberdaya Perikanan Laut di Indonesia. Jakarta.

4. Hidayat, N., I. Nurika, dan I. Purwaningsih. 2008. Potensi Ganyong Sebagai Sumber Karbohidrat Dalam Upaya Menunjang Ketahanan Pangan. Jur. Teknologi Industri Pertanian FTP-UB Malang.

5. Irmawan, S. 2009. Status Perikanan Ikan Kembung di Kabupaten Barru. Fakultas Perikanan dan Ilmu Kelautan. Universitas Brawijaya. Malang.

6. Kartika, B., P. Hastuti, dan W. Supartono. 1988. Panduan Uji Indrawi Bahan Pangan. Universitas Gajah Mada. . Universitas Gajah Mada. Yogyakarta.

7. Ketaren, S. 1986. Pengantar Teknologi Minyak dan Lemak Pangan. UI Press, Jakarta.

8. Winarno, F.G. 2002. Kimia Pangan dan Gizi. Gramedia Pusaka Utama. Jakarta.

9. Winarna, F.G. 1993. Pangan Gizi Teknologi dan Konsumen. Gramedia Pusaka Utama. Jakarta.

10. Papunas M.E., G.S.S. Djarkasi, dan J.S.C. Moningka. 2013. Karakteristik Fisikokimia dan Sensoris Flakes Berbahan Baku Tepung Jagung (Zea Mays L), Tepung Pisang Groho (Musa acuminafe,sp) dan Tepung Kacang Hijau (Phaseolus radiates). Program Sudi Ilmu dan Teknologi Pangan Unsrat.

11. Suarni. 2012. Potensi Sorgum sebagai Bahan Pangan Fungsional. Iptek Tanaman Pangan Vol.7 No.1 2012.

12. Suyatno $2010 . \quad$ DKBM-Indonesia. http://suyatno.blog.undip.ac.id/file/2010/ 04/DKBM-Indonesia.pdf. Diakses 21 Pebruari 2018. Suyatno .2010. DKBM-Indonesia. http://suyatno.blog.undip.ac.id/file/2010/ 04/DKBM-Indonesia.pdf. Diakses 21 Pebruari 2018.

13. Widjaksono, A.T. (2013). Pengaruh ketebalan dan persen aerasi kemasan terhadap sifat fisikokimia tempe grits kacang merah (Phaseolus vulgaris L.). Institut Pertanian Bogor. 